https://ejournal.uniska-kediri.ac.id/index.php/PROFICIENCY

\title{
THE EFFECTIVENESS OF ONLINE GAME IN TEACHING VOCABULARY OF THE FIRST GRADE OF MTs NEGERI 1 KEDIRI
}

\author{
By: USWATUL LYANA
}

\begin{abstract}
The aim of the research was to analyze whether there is any effectiveness of online game in teaching vocabulary of the first grade of MTsN 1 Kediri. This research was quantitative research approach, the research design was quasy experimental by non equivalent group posttest-only. This research used two classes which became experimental group (VII C) and control group (VII E). The experimental group was taught by using online game, whereas control group was taught without online game. The instruments used in the research was multiple choice test. The procedures of using online game in teaching vocabulary are; preparation, main activities and post activity. The reasearch took 4 meetings and 1 meeting to do test. The result is online game in teaching vocabulary is effective. It can be proven by the result of t-test: the mean score of experimental group ( $\mathrm{M}=$ 88.29) was higher than control group $(M=83.92)$, and independent-samples t-test which values of the sig. 2-tailed was $0.29 \%$ or 0.029 and $0.029<0,05$. This result suggests that the use of media online game in teaching vocabulary is interesting way to learn English.
\end{abstract}

Key word: effectiveness, online game, vocabulary

\section{INTRODUCTION}

Talking about English cannot be separated from 4 skills that must be achieved. They are speaking, reading, writing and listening. Speaking and writing are productive skill that learners doing. These need to produce language. They are also known as active skill. Meanwhile, reading and listening are known as receptive skill that the learners do not need to produce any language to do these, learners receive and understand it. These skills are also known as passive skill. Both of those skills need to understand vocabulary to produce or receive a language.

Vocabulary is one of the language elements which every speaker has. Vocabulary is not only The speakers might produce words when they want to speak or write something. The speakers also must know and understand any words when they read some text and listen a speech. Vocabulary is one of components of English which is essential to have by the learners of foreign language. In all language teaching, Vocabulary is one of the important factors that students must continually learn words as they learn structure and as they practice sound system. In fact, it is what makes the essence of a language. Without vocabularies, speakers cannot convey the meaning and communicate each other in a particular language. 
https://ejournal.uniska-kediri.ac.id/index.php/PROFICIENCY

Many learners of English asume that whenever they think of vocabulary, they think of learning a list of words with meanings in their native language or sometimes they are asked to memorize it. It is known that memorizing vocabulary is not easy to be done. Sometimes students can easily memorize but they don't know how to use it. Learning vocabulary in list sometimes does not satisfy the learners, they might think the cause for it is just their bad memorization. Here, the teacher can choose the best media to teach vocabulary that can be memorized and applied in daily spoken. (Decarrico,2001) states that words should not be learnt separately or by memorization without understanding; moreover,learning new words is a cumulative process, with words enriched and established as they are met again.

This is the digital era; so many things can be done by computer, handphone or gagged. People can access internet easily from their gagged. They can access many information or download the file they want. Nowadays people love to play game whether it is online or offline. The players come from different gender and ages. All of them like it. Online game tends to be game that makes the players especially the students addicted to play it everytime. Actually it depends on the personality of the players themselves if the games are used in right way, it can be useful like sharpening the brain of the player, it can be used as media in learning foreign language etc.

In this research, the researcher tries to find out the effectiveness of "magic rush" in learning vocabulary. To figure out the reasons behind the use of the game and to get a description about teacher's and student's perceptions on the use of the game and the reason why they get easily memorize and apply the vocabulary they get from online game, so that later the students get easy to acquire new vocabulary to speak in English well. By playing online game that almost everyone loves, the learners can find the easy way to acquire new vocabulary. They are going to feel fun, relaxed and enjoyed, and they are asked to memorize the vocabulary in different way.

From the explanation above, it can be seen that many students love to play game and magic rush apropriates to teach vocabulary at the seventh grade students in second semester that follows basic competence, So the researcher uses it as the Tittle The Effectiveness Of Online Game In Teching Vocabulary of The Seventh grade Students Of Mtsn 1 Kediri.

\section{METHODS}

The research method used in this research was Quasy experimental by Nonequivalent group, Posttest-Only. This research used two classes which are experimental class and control class

MTsN 1 Kediri was selescted as the research. It is located in $\mathrm{Jl}$. Canda Birawa Stadium No. 01 Tulungrejo, Pare, Kediri, East Java. The subject of this research were the students of MTs Negeri 1 Kediri from VII class in the academic year 2017 - 2018. In this research, choosing the class which becomes 
https://ejournal.uniska-kediri.ac.id/index.php/PROFICIENCY

experimental and control class. the experimental class was VII $\mathrm{C}$ and VII E as control class. So these classes were the subject of this research which total 75 students.

The instrument used in this research was a writing test. In this research took one of the test, namely post-test only. . The test administered for control and experimental group was the same. For control class, the test was given to students after teaching writing descriptive text without Silent Short Movie and for experiment group, the test was given students after teaching writing descriptive text by using Silent Short Movie and also the test was given in the last meeting. The students were asked to choose one of the topics to be written and they were asked to make a paragraph of descriptive text in \pm 140 words, the time allocation for doing the test was 60 minutes. After that, the students were asked to make descriptive paragraph based on their own words. Their writing would be scored based on some aspects, those were; content (13 - 30), organization $(7-20)$, vocabulary $(7$ - 20), language use $(5-25)$, and mechanics $(2-5)$. Instrument was tried out toVIII B with 35 students and also the questionnaire how they understood the intruction of question by asking 5 question. Before the instrument were tested to experimental and control groups. It was done to find out the instrument quality, they were; its validity, its reliability, its normality and its readibility.

\section{A. The validity of instrument}

According to Arikunto (2006), If value in significant 2 tailed more than $5 \%$, it is called invalid. But if value in significant 2 tailed less than $5 \%$ but more than $1 \%$, the data is valid in 5\% signifivance level. Then, if the value is less than $1 \%$ so, the data is valid in $1 \%$ significance level. While the data above, it can be seen that the questions of this study were valid.

It was symbolized by rpbi. The validity was computed by using SPSS version 20. The result of SPSS would show us two signs, those were one asterisk (*) and two asterisks $(* *)$. One asterisk showed that the aspects were valid enough and two asterisks showed that the aspects were very valid. The aspects given were supposed to be valid. The validity values of each aspect were; (1) $\mathrm{V}_{1} 0,566^{* * *}$, (2) $\mathrm{V}_{2} 0,334^{* *}$, (3) $\mathrm{V}_{3}$ $0,735^{* *}$, (4) $\mathrm{V}_{4} 0,658^{* *}$, (5) $\mathrm{V}_{5}$ $0,436^{* *}$ (6) $\mathrm{V}_{1} 0,566^{* *}$, (7) $\mathrm{V}_{7} 0,334^{*}$, (8) $\mathrm{V}_{8} \quad 0,592^{* * *}$ (9) $\mathrm{V}_{9} \quad 0,658^{* *}(10)$ $\mathrm{V}_{10} \quad 0,487^{* *}(11) \mathrm{V}_{11} 0,436^{* *}$ (12) $\mathrm{V}_{12} \quad 0,487^{* *}(13) \mathrm{V}_{13} 0,658^{* * *}$ (14) $\mathrm{V}_{14}$ $0,601^{* *}(15) \quad V_{15} \quad 0,666^{*} \quad(16) \quad V_{16}$ $0,838^{* *} \quad$ (17) $V_{17} \quad 0,566^{* *}(18) \quad V_{18}$ $0,592^{* *}(19) \quad V_{19} \quad 0,518^{* *}$ (20) $V_{20}$ $0,355^{* *}$ While the data above, it can be seen that the questions of this study were valid.

B. The reliability of instrument

The reliability of instrument was needed to make sure that the instrument could be consistent if it was used in other time. It meant that the instrument was reliable. The instrument is computed by using SPSS version 20. The result of reliability testing by using SPSS 20 can be seen on the table 3.2. 
https://ejournal.uniska-kediri.ac.id/index.php/PROFICIENCY

Table 3.2 Reliability Analysis

\begin{tabular}{|c|c|}
\hline \multicolumn{2}{|l|}{ Reliability Statistics } \\
\hline Cronbach's Alpha & N of Items \\
\hline, 740 & 21 \\
\hline
\end{tabular}

From the table above, the instrument of the research has reliability. According to Nunally (2005) the instrument can be said reliable if it is higher than 0.601 . it means that the whole instruments are reliable.

\section{The Normality of Instrument}

The normality of instrument was shown in histogram. If the histograms had a peak, it meant that the data could be included in normal distribution. The normality was computed by using SPSS version 22 .

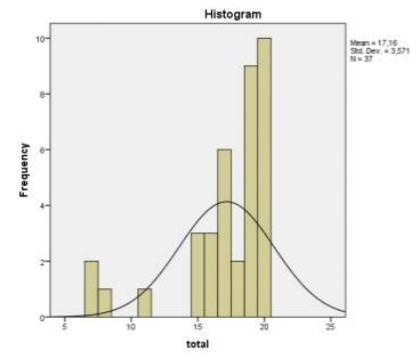

Figure 3.1 Normality Curve

Based on the figures above, it can be concluded that the data of students' achievement in both instruments were various and distributed normally. It was proven by the peak that appeared in the diagram.

\section{RESEARCH PROCEDURE}

Here is facilitating the students to learn vocabulary through online game (Magic rush). All students download and install Magic Rush game in their cell phone. They have to get 9 level of this game to open chatting mode.the arena used in this meetings are St debiya, Holy tree, Outskirt and river bank It takes five meetings included the final test to do this research. All meeting has the same treatment but different topic and level game. The procedure is; (1) Students open the game on their mobile phone and group chat,(2) Students are given topic by teacher then they play in normal stage for 10 minutes,(3) Students analyze the thing at arena then they open group chat and report the vocabulary they get from the game they play, If they do not understand the words they can look up on their dictionary or ask by typing "how to say....in English", (4) The students play the game in some stage that shown by teacher, (5) The teacher ask the students to write the vocabulary on their own book, (6) asking the students to repeat the correct pronunciation for 3 times, (7) Asking the students to fill the text about the topic. The final test takes 60 minutes and the test is multiple choice by 20 items.

To test the hypotheses, the writer also used inferential statistics, It was t-test. It was used to determine whether the is a significant difference between the means of two groups. Independent $t$-test was used in this research. The writer used SPSS version 20 to analysis of t-test. It is used to differentiate between score of experimental and control group. After finding the t-test result or t-value, the next step is interpreting it. If the significance is lower than 5\%, the difference between two groups is found and Silent Short Movie is effective. 
https://ejournal.uniska-kediri.ac.id/index.php/PROFICIENCY

\section{RESEARCH FINDING}

After the treatment was given to the experimental group that was teaching by using Online game Magic Rush; while the control group was teaching without using Online game Magic Rush, then the researcher conducted the post-test.

From the post-test it was found the scores of experimental group (see table 4.1) and control group (see table 4.4).

Table 4.1 experimental class

\section{A. Experimental Class}

\begin{tabular}{|llr|}
\hline \multicolumn{2}{|l}{$\begin{array}{l}\text { Etatistics } \\
\text { EXPERIMENT }\end{array}$} & \\
N & Valid & 38 \\
Mean & Missing & 0 \\
Std. Error of Mean & 88,29 \\
Median & 1,452 \\
Mode & 90,00 \\
Std. Deviation & & 85 \\
Variance & & 8,950 \\
Range & & 80,103 \\
Minimum & & 40 \\
Maximum & & 60 \\
Sum & & 3355 \\
& 25 & 85,00 \\
Percentiles & 50 & 90,00 \\
& 75 & 95,00 \\
\hline
\end{tabular}

The highest score gotten by students in experimental class is 100 , whereas the lowest score is 60 . The range of the highest and lowest score is 40 . The mean score is 88,29 . The median score is 90 while its mode is 85 . The standard deviation shown is 1,452 .

Frequency is number of times the scores appear in computation. There are 8 kinds of scores shown from the lowest to the highest. It means that the students' reading comprehension achievement is various. To make it clearer, the frequency of the students' achievement in experimental class is presented in table 4.2. The frequency table is presented on the following page.

Table 4.2 Frequency of the Students' vocabulary Achievement in experimental class

\begin{tabular}{|r|r|r|r|r|r|}
\hline \multicolumn{7}{|c|}{ EXPERIMENT } \\
\hline \multicolumn{1}{|c|}{} & Frequency & Percent & $\begin{array}{c}\text { Valid } \\
\text { Percent }\end{array}$ & $\begin{array}{c}\text { Cumulative } \\
\text { Percent }\end{array}$ \\
\hline \multirow{7}{*}{ Valid } & 60 & 1 & 2,6 & 2,6 & 2,6 \\
\cline { 2 - 6 } & 70 & 1 & 2,6 & 2,6 & 5,3 \\
\hline & 75 & 1 & 2,6 & 2,6 & 7,9 \\
\cline { 2 - 6 } & 80 & 4 & 10,5 & 10,5 & 18,4 \\
\cline { 2 - 6 } & 90 & 11 & 28,9 & 28,9 & 47,4 \\
\cline { 2 - 6 } & 95 & 3 & 23,7 & 23,7 & 71,1 \\
\cline { 2 - 6 } & 100 & 8 & 21,1 & 21,1 & 100,0 \\
\cline { 2 - 6 } & Total & 38 & 100,0 & 100,0 & \\
\hline
\end{tabular}

Table 4.2 shows that; $2,6 \%$ or 1 student gets $60 ; 2,6 \%$ or 1 student gets $70 ; 2,6 \%$ or 1 student gets 75 ; $10.5 \%$ or 4 students get $80 ; 28.9 \%$ or 11 students get $85 ; 23,7 \%$ or 9 students get $90 ; 7,9 \%$ or 3 students get $95 ; 21,1 \%$ or 8 students get 100 . Most of the student in the experimental class got 80 for their test. The bar chart is presented in the following pages;

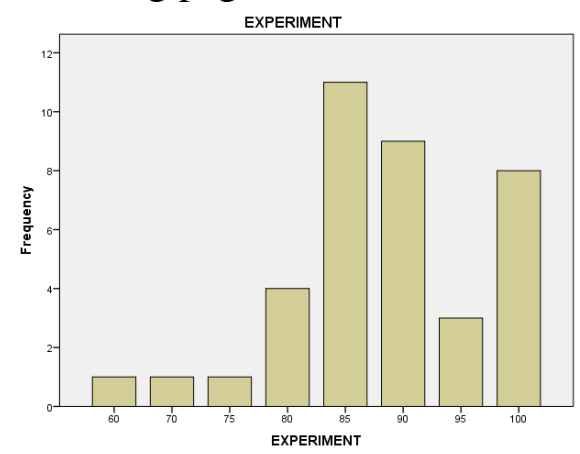


https://ejournal.uniska-kediri.ac.id/index.php/PROFICIENCY

The students's score are clasified in to some categories. Table of categorization is adapted fom Sugiyono (2011)

Table 4.2 Category for the Students' Achievement in Experimental Group

\begin{tabular}{ll}
\hline Score & Category \\
\hline $80-100$ & Very Good \\
\hline $66-79$ & Good \\
\hline $50-65$ & Enough \\
\hline $40-49$ & Poor \\
\hline $0-39$ & Very Poor \\
\hline
\end{tabular}

The classification could make easier to show how many students got value in very good level, good level, fair level, bad level, and very bad level. The students who get score in interval $61-80$ (good) are 6 students and in interval 41-60 (fair) is 1 student. Meanwhile, the students who get score in interval $81-100$ (very good) are 31 students

\section{B. Control Group}

\begin{tabular}{|l} 
Statistic Data for Control class \\
\begin{tabular}{|lrr}
\hline Statistics & \\
CONTROL & & \\
N & Valid & 37 \\
Mean & Missing & 1 \\
Std. Error of Mean & 83,92 \\
Median & & 1,316 \\
Mode & & 85,00 \\
Std. Deviation & 85 \\
Variance & & 8,005 \\
Range & & 64,077 \\
Minimum & & 40 \\
Maximum & & 55 \\
Sum & & 95 \\
& 25 & 85,50 \\
Percentiles & 50 & 90,00 \\
\hline
\end{tabular}
\end{tabular}

From table 4.4, it can be seen that the highest score is 95 and the lowest score is 55 while its range is 40. The mean shown in the group is 83,92 . the median is 85 while its mode is 85 . The standard deviation is 8,005 .

Frequency is number of times the scores appear in computation. There are 8 kinds of scores shown from the lowest to the highest. It means that the students' reading achievement is various. To make it clear, the frequency of students' achievement is presented in table 4.5. The table of frequency is presented in following page.

Table 4.5

Frequency of the Students' Writing Achievement in Control Group

\begin{tabular}{|c|c|c|c|c|c|}
\hline & & & ONTROI & & \\
\hline & & F & Percent & $\begin{array}{l}\text { Valid } \\
\text { Percent }\end{array}$ & $\begin{array}{c}\text { Cumulative } \\
\text { Percent }\end{array}$ \\
\hline & 55 & 1 & 2,6 & 2,7 & 2,7 \\
\hline & 60 & 1 & 2,6 & 2,7 & 5,4 \\
\hline & 70 & 1 & 2,6 & 2,7 & 8,1 \\
\hline & 75 & 1 & 2,6 & 2,7 & 10,8 \\
\hline Valid & 80 & 5 & 13,2 & 13,5 & 24,3 \\
\hline & 85 & 16 & 42,1 & 43,2 & 67,6 \\
\hline & 90 & 11 & 28,9 & 29,7 & 97,3 \\
\hline & 95 & 1 & 2,6 & 2,7 & 100,0 \\
\hline & Total & 37 & 97,4 & 100,0 & \\
\hline Missing & System & 1 & 2,6 & & \\
\hline Tot & & 38 & 100,0 & & \\
\hline
\end{tabular}

The frequencies of score achieved by the students are; $2,6 \%$ or 1 student gets $55 ; 2,6 \%$ or 1 student gets $60 ; 2,6 \%$ or 1 student gets 70 ; $2,6 \%$ or 1 student gets $75 ; 13,2 \%$ or 5 students get $80 ; 42,1 \%$ or 16 student gets $85 ; 28,9 \%$ or 11 students get 90 ; and $2,6 \%$ or 1 students get 
https://ejournal.uniska-kediri.ac.id/index.php/PROFICIENCY

95. Most of the student in the control class got 85 for their test. The bar chart is presented as follows;

The bar chart is presented on the following page;

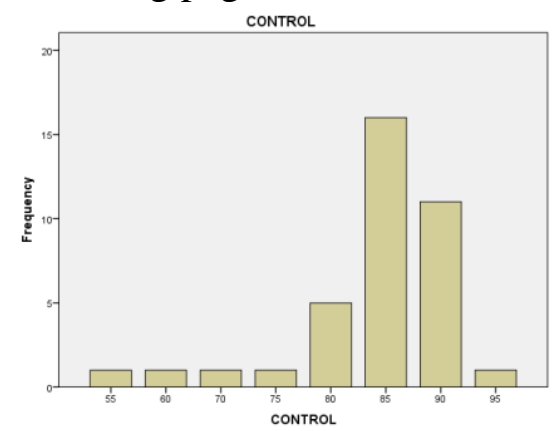

Figure 4.3 Frequency of the Students' Writing Achievement in Control Group

The students' scores are classified into some categories. the classified of categories were explained in table 4.6. The categories are presented as follows

Table 4.6 Category for the Students' Achievement in Experimental Group

\begin{tabular}{ll}
\hline Score & Category \\
\hline $80-100$ & Very Good \\
\hline $66-79$ & Good \\
\hline $50-65$ & Enough \\
\hline $40-49$ & Poor \\
\hline $0-39$ & Very Poor \\
\hline
\end{tabular}

The students who get score in interval 41- 60 (fair) are 2 students $61-80$ (good) are 7 students. Meanwhile, the students who get score in interval $81-100$ (very good) are 28 students.

Interpreting the Result of Significant Difference between the Students' Writing Achievement in Experimental and Control Group

After finding the results of both groups, the significant difference between students' reading comprehension achievement in control and experimental class is calculated. SPSS version 2.0 is used to analyze the data. The result is shown in table 4.3. The table is presented on the following page.

\begin{tabular}{|cccccc|}
\hline \multicolumn{1}{|l|}{ Group Statistics } & & & & \\
\multirow{5}{*}{ Score } & Experiment & 38 & 88,29 & 8,950 & 1,452 \\
& Control & 37 & 83,92 & 8,005 & 1,316 \\
\hline
\end{tabular}

Table 4.7 reveals a difference in mean value between the control class $(\mathrm{M}=83.92, \mathrm{SD}=8.005)$ and the experimental class $(\mathrm{M}=88.29$, $\mathrm{SD}=8,950)$. In order to examine whether the experimental class and the control class differed significantly in the test achievement, an independent-samples t-test was conducted using an alpha level of 0.05 . The result is indicated in table 4.8. The table presented in the following page. 


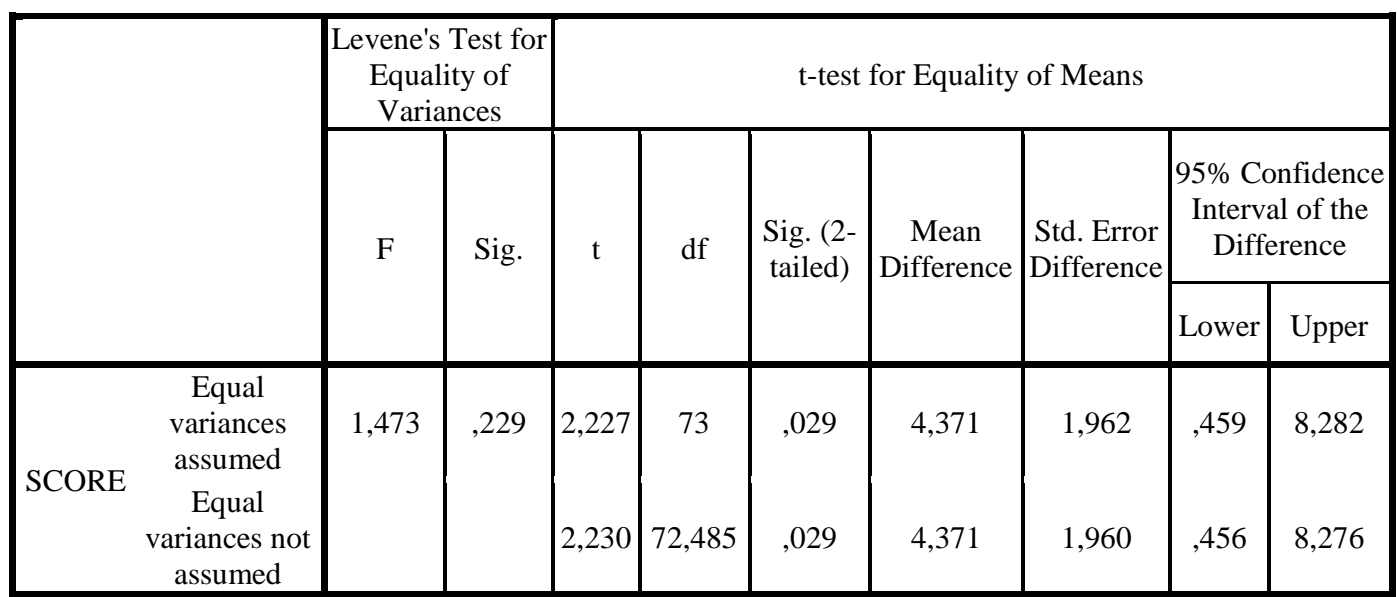

The interpretation of the table above is; there is significant difference between two groups if sig. (2-tailed) value is the same as or is lower than $5 \%$ or 0.05 . From table 4.8 , it can be seen that the experimental class outperformed the control class in vocabulary mastery with $\mathrm{t}=2.227, d f=73$ and $\mathrm{P}=.029$ and $95 \%$ confidence interval ranging from 0.459 to 8,282 . From the sig. (2-tailed) we can see the $\mathrm{P}$ is lower than $5 \%(0.029<0.05)$. So, it can be conclude that the t-value is significant in 5\% significant level. It means that there is significant difference between control and experimental class.

\section{The Effectiveness of Using Online} Game (Magic Rush) in Teaching vocabulary of Descriptive Text.

The objective of this research is to find out the effectiveness of using online game (Magic Rush) in teaching vocabulary of descriptive text. After analyzing the results of both groups, independent-samples ttest is calculated.

The result of t-test shows that the mean difference is 4,371 with sig. (2-tailed) value .029. The value indicates that there is significant difference between both groups. Thus, it can be concluded that the use of online game (Magic Rush) is effective.

Therefore, the alternative hypothesis which stated that online game (Magic Rush) is effective to be used in teaching reading comprehension of descriptive text at the seventh grade of MTsN 1 Kediri' is accepted.

\section{DISCUSSION}

After finding the students' vocabulary in control and experimental group, the next step done is finding significant difference between them. The test result shows that the mean of experimental group is 88,29 whereas the mean of control group is 83.99. Meanwhile, their standard error mean values are 1,452 and 1.316. The standard deviation values of both groups are 8,950 and 8,005 . Furthermore, the mean difference between both groups is 1,962 . These result indicate that the significant difference of mean value between the control group and the experimental group was found. 
https://ejournal.uniska-kediri.ac.id/index.php/PROFICIENCY

So, it can be concuded that there is significant difference between the students in control and the students in experimental group.

The result of t-test shows that: 1) the mean score of experimental group $(\mathrm{M}=80.95)$ is higher than control group $(\mathrm{M}=77.44)$, and 2$)$ The mean difference is 3.124 with the sig (2-tailed) value $0.3 \%$ or 0.003 . Thus, it can be concluded that the Silent Short Movie is effective.

\section{CONCLUTION AND SUGGESTION Conclution}

From the result of the research, it can be concluded that:

1) The students' vocabulary achievement in experimental group, which is taught by using online game, is in very good category with the mean score 88,29 .

2) The students' vocabulary in control group, which is not taught by online game is in very good category with the mean score 83,92 .

3) There is significant difference between the experimental and control group's achievement. The result shows that experimental group's achievement is higher than control one. It is also proven by the result of independentsamples t-test which values of sig. 2-tailed is $0.029(\mathrm{P}, 0.05)$.

4) Online game is effective to be used in language teaching specifically in teaching vocabulary.

\section{Sugesstion}

1) Teacher. This research can be useful for teacher in providing e new media to teach vocabulary. Teacher can know the advantage and disadvantage using the media in teaching vocabulary. The Teacher also can develop the media used from this research based on the students' ability or something famous nowadays.

2) The principal of MTsN 1 Kediri. This research can be useful for institute in providing $\mathrm{e}$ new knowledge to apply in teaching vocabulary. This research also can be a map for institute to develop media and method to the students.

3) Reader. This research might increase the readers' knowledge about the using of online game in teaching vocabulary.

4) Next researcher. The result of this research can be used as a reference for the next research in the same topic and purpose for the other population or different field. The other researchers are suggested to attempt to hold the same kind of research with different sample in the use of online game (Magic Rush) strategy in order to know whether this strategy can significantly help to improve the students vocabulary mastery but the researcher suggested to be more creative in implementing those strategy in teaching vocabulary mastery, especially in descriptive text. The researcher use of varied techniques can greatly increase the motivation of the students in teaching and learning process in reading activities. 
https://ejournal.uniska-kediri.ac.id/index.php/PROFICIENCY

\section{REFERENCES}

Arikunto, Suharsimi. 2002. Prosedur Penelitian Suatu Pendekatan Praktek. Rineka Cipta. Jakarta. Azar, Betty Schrampfer and Hagen, Stacy A. 2006. Basic English Grammar, Third Edition. United States: Longman.

Daphne Bavelier.2012.the Brain \& Vision Lab,Department of Brain \& Cognitive Sciences, University of Rochester, Rochester, New York 14627, USA. Retrived from: https://m.youtube.com/watch?v =e8hzowkUkR4

Decarrico, J. S. (2001). Vocabulary Learning And Teaching. In M. Celce-Murcia (Ed.),Teaching English As A Second $\mathrm{Or}$ Foreign Language ( $3^{\text {rd }}$ Ed., Pp. 285-299). Boston: Heinle.

Elyas, Tariq \& Ibrahim Alfaki.2014.Teaching Vocabulary: The Relationship between Techniques of Teaching and Strategies of
Learning New Vocabulary Items. English Language Teaching; Vol. 7, No. 10; 2014.Canadian Center of Science and Education Hiebert, Elfrieda $\mathrm{H}$ and Kamil, Michael L. 2005. Teaching and Learning

Vocabulary, Bringing Research to Practice. London: Lawrence Erlbaum Associates.

Jeremy Haermer.Malaysia:Longman University Of Chicago Press

Pearson, P.D., Hielbert, E.H. \& Kamil, M.L, Vocabulary Assessment: What We Know And What Need To Learn. Reading Research Quarterly Vol. 42, No. 2, 2007, P. 285

Sugiyono. 2011. Metode Penelitian Kuantitatif Kualitatif $R \& D$. Bandung: Alfabeta.

Thornbury, Scott. 2002. How to Teach Vocabulary. England: Pearson Education Limit. 